\title{
THE SOCIAL/ORGANIZATIONAL FRAMEWORK OF THE OPERATION OF SUSTAINABLE KINDERGARTEN: STUDENT PRESCHOOL TEACHERS' VIEWS
}

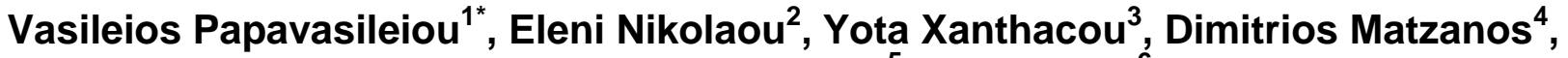 \\ Ioannis Papadomarkakis ${ }^{5}$, Maria Kaila ${ }^{6}$ \\ ${ }^{1}$ Assist. Prof. Dr., University of the Aegean, Greece, vpapavasileiou@rhodes.aegean.gr \\ ${ }^{2}$ Lecturer Dr., University of the Aegean, Greece, enikolaou@rhodes.aegean.gr \\ ${ }^{3}$ Prof. Dr., University of the Aegean, Greece, xanthakou@rhodes.aegean.gr \\ ${ }^{4}$ Dr. University of the Aegean, Greece, matzanos@rhodes.aegean.gr \\ ${ }^{5}$ Dr. University of the Aegean, Greece, papadomarkakis@rhodes.aegean.gr \\ ${ }^{6}$ Prof. Dr., University of the Aegean, Greece, kaila@rhodes.aegean.gr \\ ${ }^{*}$ Corresponding author
}

\begin{abstract}
The aim of the present research is to explore students' views about the social/organizational framework of the operation of the sustainable kindergarten. The research was conducted between March to May 2017. Case study was chosen as the main method, employing a questionnaire as the main methodological tool. The research population was the fourth year students of the Department of Preschool Education Sciences and Educational Design of the University of the Aegean in Rhodes (Greece). The sample was selected by random sampling.

The results of this research study indicate that the majority of students consider the "sustainable school" identical to "ecological school" and "bioclimatic school", as they emphasize the infrastructure. It is also noted that the majority of students of the research sample disagrees with the view that a sustainable kindergarten is sometimes governed democratically and sometimes in an authoritarian way. However, the total number of students who express the opposite view or respond that they do not know, are more than half.

Moreover, research data indicate that the majority of students agree with the participation of pupils in decision-making regarding the operation of a sustainable kindergarten. They also agree with the view that the local community participates in the activities-actions of a sustainable kindergarten. However, the percentages of the participants expressing the opposite view or not expressing opinion are very high. In addition, as far as the management of a sustainable kindergarten is concerned, the majority of the respondents state that the role of the head of the kindergarten is dominant, while the role of important agents, such as the students, teachers' association, parents' association and the local community, is underestimated.
\end{abstract}

Keywords: Preschool education, sustainable kindergarten, social/organizational framework 


\section{INTRODUCTION}

The structure of a sustainable school is very well organized, as the three main levels of school operation are emphasized: a) pedagogical and b) technical / economic and c) social / organizational (Posch, 1999; Papavasileiou et al. 2017). These three levels of operation of the educational ecosystems interact with each other directly, constituting a wider indivisible whole. In this context, they are not treated individually and in a fragmented manner but holistically as interrelated elements (Papavasileiou, 2015).

At pedagogical level, the purpose of Sustainable School is to help students and the entire school community acquire useful learning experiences as well as get into contact with real situations of everyday life. Through cross-curricular approaches, collective activities and experiential experiences, they will be able to understand complex, composite and multilevel relationships, to cultivate critical, creative and systemic thought, and undertake active actions (Scoullos \& Malotidi, 2004; Tilbury, 2011).

At the technical / economic level, the necessary conditions are the upgrading of the infrastructure by using environmentally friendly materials, the redevelopment of the school space, the reorganization of the external premises of the school, the wise management of natural resources and, in general, the sustainable design and its realization (Posch, 1999).

At the social / organizational level, it is intended to ensure the democratic processes and prerequisites for equality and justice both inside and outside school. The actors of the school community, in co-operation with the local community, local bodies, services and organizations, make the decisions regarding the proper operation of the school democratically and through cooperative and consensual procedures (Ali Khan, 1996).

Sustainable development is the organizing principle of sustainable school that should govern educational reality. Sustainable School seeks to achieve environmental awareness, connection to local community and active citizenship (DfES, 2005). It is also interested in developing educational environments and learning experiences that will enable students to work towards ensuring quality of life (Breiting et al., 2005; Gough, 2005).

Sustainable school is based on modern pedagogical principles (Huckle, 2002). Its structure is flexible with multiple goals (Sterling, 2001 - 2011). Its thematic sections are based on local issues, which are, however, linked to regional and global issues (Cruickshank \& Fenner, 2012). Among the key issues are included the following: ecological diversity, ecological principles and ecosystems, natural resource management, climate change, disaster prevention, energy, waste, health and quality of life, peace and human security, human rights, democracy, participatory decision making, gender equality, cultural diversity, intercultural understanding, consumerism, water, rural and urban development, corporate social responsibility and globalization (Tilbury \& Mulà, 2009).

The approach to these issues is not aimed only to the transmission of knowledge but educators and students work together to acquire this knowledge and play an active role in shaping the environment of their educational institutions (Papavasileiou et al., 2017). Decision-making is participatory, as pupils participate in decision-making on how they should learn. Moreover, the possibility of application is provided, since learning experiences are integrated into everyday personal and professional life and are locally focused (UNESCO, 2005; UNESCO, 2017).

Students approach environmental problems not only as ecological but also as social, political, moral, cultural and economic, in the context of a sustainable school, employing a critical and systemic approach. They are seeking for effective solutions as they realize that environmental issues constitute areas of controversy at both local and international level (Papavasileiou, 2015).

The Sustainable School promotes sustainable action initiatives involving all members of the school unit which, in cooperation with the local community, are actively involved in designing - planning and implementing these diverse actions. Active participation and the successful development of actions between the actors of education and the local community contribute to linking the school with society with the aim of achieving sustainable development (Henderson \& Tilbury, 2004; Gough, 2005).

The curriculum is rich without being heavily loaded, responding to modern scientific and social requirements, both at the individual and collective level (Tilbury, 1995; Woo et al., 2012). It is intended to ensure the highest level of active participation of trainees (Jensen \& Scnack, 1997; Scnack, 1998; Jensen, 2002; Jensen \& Scnack, 2006; Pozzi et al., 2007).

Sustainable school decision-making is the result of the principal's harmonious cooperation with teachers, pupils, parents, local authorities and the local community on issues related to both the administrative and the educational function of the school. The responsibilities are shifted from the director to the teachers' 
association, from the individual to the collective form of administration with democratic processes. Active participation of students is also considered important, as their ideas, suggestions and actions can bring about positive changes at all levels of school operation (Papavasileiou, 2015).

The leadership of Sustainable School has a strong vision, high expectations, impetus and determination, and it is focused on teaching and learning. Moreover, this leadership has a deep moral purpose and it is shared, that is, it is participatory (Harris, 2008). Sustainable school leadership is very important. It is transmitted, it lasts, it does not harm but it benefits the environment, promotes coherent diversity, develops and does not exhaust natural and human resources. It also utilizes the best examples of the past to create an even better future (Hargreaves and Fink, 2003; 2006).

The "Seven Principles of Sustainable Leadership" stem from the above description and they are the following: sustainable leadership supports and maintains supported learning, ensures success over time, supports the leadership of others, raises issues of social justice, develops and reduces human and natural resources, develops environmental diversity and capacity and takes active action on the environment (Hargreaves and Fink, 2003).

In conclusion, the concept of "sustainable school" is often approached one-dimensionally, as it emphasizes infrastructure and it is limited within a narrow framework of the institution that simply works without polluting the natural environment. However, beyond the processes and the ways in which it operates and manages its resources, which are obviously inspired by an ecological logic and practice, firstly, sustainable school is primarily the institution that cultivates students' ability to envision and build a new world based on the principles of sustainability. Finally, "sustainable" is not just the "ecological" school - regarding its function but the school that shapes "ecological" consciousness (Papavasileiou, 2015).

\section{METHODOLOGY}

In order to achieve the goals of a sustainable school, it is necessary to apply modern principles, which constitute a democratic social / organizational framework of operation. The aim of this research is to explore students' future preschool teachers views on the social / organizational framework of the sustainable kindergarten.

The research data presented in this study are part of a wider research, as it included the three axes of the sustainable kindergarten: pedagogical, technical / economic and social / organizational. The research was conducted between March and May 2017, and case study was selected as the main method. A questionnaire was the main methodological tool for collecting a variety of information. The questionnaire used in this research was mainly consisted of closed questions (Bell, 2010; Cohen, Manion \& Morrison, 2011; Bryman, 2012).

The fourth year students of the Department of Preschool Education Sciences and Educational Design at the University of the Aegean in Rhodes (Greece) were the research population. The selection of the sample was based on random sampling. As regards the gender of students of the research sample, 34 were men (19.4\%) out of the 175 students and 141 were women (80.6\%). The axes of the survey were the principles which constitute the social /organizational framework for the operation of the sustainable kindergarten.

Initially, the selection of students of the research sample was made and the questionnaires were administered. After collecting the questionnaires, we proceeded to the "content analysis" and the categorization of the answers of each of the open questionnaires of the survey questionnaire, followed by the coding of the participants' answers to all the questions and the statistical processing and analysis.

\section{RESULTS}

The research data presented in this paper are part of a wider research study, as it consists of the three main axes of the operation of the sustainable kindergarten. In the context of the present study, the responses of the students to the questions of one research axis are presented, as they refer to the social/organizational framework of the operation of the sustainable kindergarten.

According to the research data of Table 1, 129 out of the 175 students of the sample (or $73,7 \%$ ) respond that they are familiar with the term "Sustainable Kindergarten, whereas 46 (or 26,3\%) state that they are not familiar. 
IJAEDU- International E-Journal of Advances in Education, Vol. III, Issue 9, December 2017

Table 1. Distribution of frequencies of the participants' responses regarding the "Sustainable Kindergarten".

\begin{tabular}{|c|c|c|}
\hline $\begin{array}{c}\text { Are you familiar with the term "Sustainable } \\
\text { Kindergarten"? }\end{array}$ & N & $\%$ \\
\hline Yes & 129 & 73,7 \\
\hline No & 46 & 26,3 \\
\hline Total & 175 & 100 \\
\hline
\end{tabular}

Table 2 presents the distribution of frequencies of the responses of the sample regarding their ability to define the concept "Sustainable Kindergarten", when they are asked. 95 out of 175 students (or 54,3\%) state that they are able to define "the Sustainable Kindergarten", whereas 80 (or $45,7 \%$ ) respond that they are not familiar with the term.

Table 2. Distribution of frequencies of the responses of students' sample regarding their ability to define the term "Sustainable Kindergarten".

\begin{tabular}{|c|c|c|}
\hline $\begin{array}{c}\text { If you are asked to define the term } \\
\text { "Sustainable kindergarten" }\end{array}$ & N & $\%$ \\
\hline Yes & 95 & 54,3 \\
\hline No & 80 & 45,7 \\
\hline Total & 175 & 100 \\
\hline
\end{tabular}

According to Table 3, 65 students (or $37,1 \%$ ) respond that they do not know if the concepts "Sustainable Kindergarten" and "Ecological Kindergarten" are identical, 59 (or 33,8\%) responded "Yes", that is the concepts "Sustainable Kindergarten" and "Ecological Kindergarten" are identical, whereas 51 students (or $29,1 \%)$ responded correctly "No", that is, these two concepts have different semantic meaning.

Table 3. Distribution of frequencies of the responses of the students' sample regarding their perceptions about whether the terms "Sustainable Kindergarten" and "Ecological Kindergarten" are identical.

\begin{tabular}{|c|c|c|}
\hline $\begin{array}{c}\text { Are the concepts } \\
\text { "Sustainable Kindergarten" } \\
\text { and "Ecological } \\
\text { Kindergarten" identical? }\end{array}$ & N & $\%$ \\
\hline Yes & 59 & 33,8 \\
\hline No & 51 & 29,1 \\
\hline I do not know & 65 & 37,1 \\
\hline Total & 175 & 100 \\
\hline
\end{tabular}


Table 4 shows that 90 students (or 51,40\%) respond that "They do not know" whether the concepts "Sustainable Kindergarten" and "Bioclimatic Kindergarten", are identical, 32 (or 18,30\%) respond "Yes" that is, the terms "Sustainable Kindergarten" and "Bioclimatic Kindergarten" are identical, whereas, 53 students (or $37,15 \%$ ) respond correctly "No", that is that these two concepts have different semantic meaning.

Table 4. Distribution of frequencies of the responses of the students' sample regarding whether the concepts "Sustainable Kindergarten" and "Bioclimatic Kindergarten" are identical.

\begin{tabular}{|c|c|c|}
\hline $\begin{array}{c}\text { Are the concepts } \\
\text { "Sustainable } \\
\text { Kindergarten" and } \\
\text { "Bioclimatic Kindergarten" } \\
\text { identical? }\end{array}$ & N & $\%$ \\
\hline Yes & 32 & 18,3 \\
\hline No & 53 & 30,3 \\
\hline I do not Know & 90 & 51,4 \\
\hline Total & 175 & 100 \\
\hline
\end{tabular}

To the question regarding whether the sustainable kindergarten is sometimes managed in a democratic manner and sometimes in an authoritarian manner, as Table 5 shows, 85 students $(48,6 \%)$ responded "I disagree", whereas 36 responded "I agree" (20,6\%) and 54 responded that they had no opinion $(30,8 \%)$.

Table 5. Distribution of frequencies of the responses of the students' sample regarding the democratic management of sustainable kindergarten

\begin{tabular}{|c|c|c|}
\hline $\begin{array}{c}\text { The sustainable } \\
\text { kindergarten is sometimes } \\
\text { managed in a democratic } \\
\text { manner and sometimes in } \\
\text { an authoritarian manner }\end{array}$ & $\mathbf{N}$ & $\%$ \\
\hline I agree & & \\
\hline I disagree & 36 & 20,6 \\
\hline I do not know & 85 & 48,6 \\
\hline Total & 54 & 30,8 \\
\hline
\end{tabular}

The distribution of frequencies of the responses of the research sample of students regarding whether the participation of preschool students in decision making is proper to be avoided due to their age, is presented in Table 6. Research data show that 58 out of the 175 students responded "Yes" (33,1\%), 72 responded "No" $(41,1 \%)$ and 45 responded that "they do not know" (25,8\%).

Table 6. Distribution of frequencies of the responses of students' sample regarding whether it is proper to be avoided the participation of preschool students to decision making in the context of sustainable kindergarten due to their age.

\begin{tabular}{|c|c|c|}
\hline $\begin{array}{c}\text { The participation of } \\
\text { preschool students in } \\
\text { decision making in the } \\
\text { context of sustainable } \\
\text { kindergarten should be } \\
\text { avoided due to their age }\end{array}$ & $\mathbf{N}$ & $\%$ \\
\hline Yes & & \\
\hline No & 58 & 33,1 \\
\hline I do not know & 72 & 41,1 \\
\hline Total & 45 & 25,8 \\
\hline
\end{tabular}

Table 7 presents the distribution of frequencies of the responses of students' sample regarding whether they believe that the local society is absent from the activities-actions of sustainable kindergarten. Research data indicate that 42 out of 175 students (24\%) responded "Yes", 76 responded "No" (43,4\%) and 57 responded that they do not know $(32,6 \%)$. 
IJAEDU- International E-Journal of Advances in Education, Vol. III, Issue 9, December 2017

Table 7. Distribution of frequencies of the responses of students' sample of the Department of Sciences of Preschool Education and Education Design regarding their beliefs whether the local society is absent from the activities-actions of sustainable kindergarten.

\begin{tabular}{|c|c|c|}
\hline $\begin{array}{c}\text { Local society is absent from } \\
\text { the activities-actions of } \\
\text { sustainable kindergarten }\end{array}$ & N & $\%$ \\
\hline Yes & 42 & 24,0 \\
\hline No & 76 & 43,4 \\
\hline I do not Know & 57 & 32,6 \\
\hline Total & 175 & 100,0 \\
\hline
\end{tabular}

The last question (Table 8) was open-ended and was related to the importance of the role of various actors in the management of sustainable kindergarten.

Table 8. Distribution of frequencies of the responses of the students' sample regarding the importance of the role of various actors in the administration of sustainable kindergarten

\begin{tabular}{|c|c|c|}
\hline $\begin{array}{c}\text { The most important actor regarding } \\
\text { their role in the administration of } \\
\text { sustainable kindergarten }\end{array}$ & N & $\%$ \\
\hline School Principal & 114 & 65,1 \\
\hline Teachers' association & 29 & 16,6 \\
\hline Parents' association & 9 & 5,1 \\
\hline Students & 8 & 4,6 \\
\hline Local society & 8 & 4,6 \\
\hline Government - State & 7 & 4 \\
\hline Total & 175 & 100 \\
\hline
\end{tabular}

The content analysis of the responses of the participants indicate that 114 students regard that the most important role is the role of school principal (or 65,1\%), 29 students (or 16,6\%) consider that the most important is the role of "teachers' association", 9 students (or 5,1\%) state that "parents' association" role is the most important, 8 students (or 4,6\%) respond that the students' role is the most important and finally 8 students (or 4,6\%) consider the role of "Local Society" as the most important. 7 students (or $4 \%$ ) regard that Government-State's role is the most important.

\section{CONCLUSIONS}

First of all, the research data of the present research study extract important information regarding students' views, future preschool teachers, about the social-organizational context of sustainable kindergarten. Then, the interpretation of the data is attempted and conclusions are extracted with regard to the research axis.

At first, although the students of the research sample responded that they are familiar with the term "Sustainable Kindergarten", later they cannot define it, when they are asked the relevant question. The percentage of students is lower to the hypothetical question, whether they are able to define it, as few more than half, respond positively.

Subsequently, when they were asked to compare the "Sustainable Kindergarten" with the "Ecological Kindergarten" and the "Bioclimatic Kindergarten", research data indicate that one third of the students 
consider that the sustainable school is identical to "the ecological school" and "bioclimatic school", as they highlight the infrastructure, whereas a high percentage of students state that they do not know. Generally, the majority of the sample is not familiar with the differences among these three types of schools.

Moreover, the higher percentage of the students of the research sample disagrees with the view that the sustainable kindergarten is sometimes administered in a democratic manner and sometimes in an authoritarian manner. However, the students of the sample that express the opposite view or respond that they do not know are in total more than half.

Furthermore, the higher percentage of students agree with the participation of students in decision making regarding the operation of sustainable kindergarten and that the local society should participate in the activities-actions of sustainable kindergarten, whereas the percentage of students that express the opposite point of view or those who do not express opinion are very high.

In addition, as far as the administration of the sustainable kindergarten is concerned, the majority states that the role of school principal is dominant, whereas the percentages for the role of the other actors of school community are very low, such as the students, teachers' association and local society. Generally, the role of important factors that can contribute to the democratic management of sustainable kindergarten is underestimated. The students of the sample do not seem to have understood that a school cannot be characterized as sustainable if it is not administered democratically, as the democratic leadership style is interwined with the principles of Education for Sustainable Development.

Finally, we should clarify that the findings of this research study cannot be generalized, as they apply to only one Department, the Department of Preschool Education Sciences and Educational Design, and to the students of only one academic year. However, they can be utilized as a starting point for further inquiry and for further research.

\section{REFERENCE LIST}

Ali Khan, S. (1996). A vision of a 21st-century community learning centre. In: J. Huckle \& S. Sterling (Eds), Education for Sustainability (222-227). London: Earthscan.

Bell, J. (2010). Doing your research project: a guide for first-time researchers in education health and social science (5nd ed.). Maidenhead: Open University Press.

Breiting S., Mayer, M. \& Mogensen, F. (2005). Quality Criteria for ESD-Schools. Vienna: ENSI.

Bryman, A. (2012). Social research methods. 4th ed. Oxford: Oxford University Press.

Cohen, L., Manion, L. \& Morrison, K. (2011). Research methods in Education (7th ed.). London: Routledge.

Cruickshank, H. and Fenner, R. (2012). Exploring key sustainable development themes through learning activities. International Journal of Sustainability in Higher Education, 13(3), 249-262.

Department of Education and Skills (DfES). (2005). Sustainable Schools for Pupils, Communities and the Environment: Securing the future delivering UK sustainable development strategy. Nottingham.

Gough, A. (2005). Sustainable Schools: Renovating educational processes, Applied Environmental Education and Communication, 4, 339-351.

Hargreaves A. \& Fink D. (2003). The Seven Principles of Sustainable Leadership, Educational Leadership, $61,7,1-12$.

Hargreaves, A. \& Fink, D. (2006). Sustainable leadership. San Francisco CA: Jossey-Bass.

Harris, A. (2008). Leading sustainable schools. London: Specialist Schools and Academies Trust.

Henderson, K. \& Tilbury, D. (2004). Whole-School Approaches to Sustainability: An International Review of Sustainable School Programs, report prepared by the Australian Research Institute in Education for Sustainability (ARIES) for the Department of the Environment and Heritage, Australian Government.

Huckle, J. (2002). Education for Sustainability: a guide for primary schools, National Primary Trust.

Jensen, B.B. \& Schnack, K. (1997). The Action Competence Approach in Environmental Education, Environmental Education Research, 3(2). 163-178. 
IJAEDU- International E-Journal of Advances in Education, Vol. III, Issue 9, December 2017

Jensen, B.B. (2002). Knowledge, action and pro-environmental behaviour. Environmental Education Research, 8 (3), 325-334.

Jensen, B. \& Schnack, K. (2006). The Action Competence Approach in Environmental Education. Environmental Education Research Vol. 12, No 3/4, 471-486.

Papavasileiou, V. (2015). Sustainable Development and Education: A multidimensional relationship. Athens: Diadrasi. (in Greek)

Papavasileiou, V., Nikolaou, E., Xanthacou,Y. Papadomarkakis, I., Matzanos, D. \& Kaila, M. (2017). Student preschool teachers' views about the pedagogical context of sustainable kindergarten. Proceedings of INTCESS 2017 4th International Conference on Education and Social Sciences. Istanbul, Turkey, 6-8 February, 2017

Posch, P. (1999). The Ecologisation of Schools and its Implications for Educational Policy. Cambridge Journal of Education, 29(3), 341-348.

Pozzi, F., Manca, S., Persico, D., \& Sarti, L. (2007). A general framework for tracking and analyzing learning processes in computer-supported collaborative learning environments. Innovations in Education and Teaching International, 44(2), 169-179.

Schnack, K. (1998). Why focus on conflicting interests in environmental education, in Ahlberg M. \& Fihlo, W. (Eds), Environmental Education for Sustainability: Good Environment, Good Life. Frankfurt: Peter Lang. 83-96.

Scoullos, M. \& Malotidi, V. (2004). Handbook on methods used in Environmental Education and Education for Sustainable Development, MIO-ECSDE, Athens.

Sterling, S. (2001). Sustainable Education. Devon, England: Green Books.

Sterling, S. (2011). Transformative learning and sustainability: sketching the conceptual ground. Learning and Teaching in Higher Education, Issue 5, 17-33.

Tilbury, D. (1995) Environmental Education for Sustainability: Defining the new focus of environmental education in the 1990s. Environmental Education Research 1(2), 195-212.

Tilbury, D. (2011). Education for Sustainable Development: An Expert Review of Processes and Learning. Paris: UNESCO.

Tilbury, D., Mulà, I. (2009). Review of Education for Sustainable Development Policies from a Cultural Diversity and Intercultural Dialogue: Gaps and Opportunities for Future Action. Paris: UNESCO.

UNESCO (2005). UN Decade of Education for Sustainable Development 2005-2014, International Implementation Scheme, Draft, Paris: UNESCO.

UNESCO (2017). Schools in action, global citizens for sustainable development: a guide for students. Paris: UNESCO.

Woo, Y.L., Mokhtar, M. Komoo, I. \& Azman, N. (2012). Education for Sustainable Development: A Review of Characteristics of Sustainability Curriculum. OIDA International Journal of Sustainable Development, 03(08), 33-43. 